\title{
Determination of Urine Protein Levels and Analysis of Differences in Vascular Endothelial Growth Factor Levels between Early Onset and Late Onset Preeclampsia
}

\author{
Engga Lift Irwanto ${ }^{1 *}$ (D), Eryati Darwin ${ }^{2}$ (D) S. Donel ${ }^{3}$, Djong Hon Tjong ${ }^{4}$ (D) \\ ${ }^{1}$ Department of Obstetrics and Gynecology, Faculty of Medicine, Andalas University, Padang, Indonesia; ${ }^{2}$ Department of \\ Histology, Faculty of Medicine, Andalas University, Padang, Indonesia; ${ }^{3}$ Department of Obstetrics and Gynecology, Faculty \\ of Medicine, Riau University, Riau, Indonesia; ${ }^{4}$ Department of Biology, Faculty of Mathematics and Natural Science, Andalas \\ University, Padang, Indonesia
}

Edited by: Ksenija Bogoeva-Kostovska Citation: Irwanto EL, Darwin E, Donel S, Tjong DH. Determination of Urine Protein Levels and Analysis of Differences in Vascular Endothelial Growth Factor Levels between Early Onset and Late Onset Preeclampsia. Open Access Maced J Med Sci. 2021 Jun 22; 9(B):552-556. https://doi.org/10.3889/oamjms.2021.622 Keywords: Preeclampsia; Early onset; Late onset; Urine protein; Vascular endothelial growth facto of Obstetrics and Gynano, Department Andalas University Padang, indonesa E-mail: enggadrspogk7980@gmailcom Regil. @17mail.co Accepted: 02-Jun-202 Copyright: ๑ 2021 Engga Lift Irwanto, Eryati Darwin, S. Donel, Djong Hon Tjong Funding: This research did not receive any financia Competing Interests: The authors have declared that competing interests exis competing interests exist Open Access: This is an open-ase nonCommercial 4.0 International License (CC BY-NC 4.0)

\begin{abstract}
BACKGROUND: Preeclampsia is a disease with the high mortality rate. Data indicate that $23.5 \%$ of maternal deaths due to preeclampsia. Urine protein testing is essential for pregnant women to discover the function of kidney during pregnancy and to identify the presence of preeclampsia, both mild and severe, which it can lead to eclampsia. Preeclampsia based on onset can also be detected by examining serum biomarkers of vascular endothelial growth factor (VEGF)

AIM: The aim of this study was to overview the urine protein levels and analyzed the differences serum VEGF levels between the early and late onset of preeclampsia.

MATERIALS AND METHODS: This study used design of the cross-sectional comparative study in RSUP DR. M Djamil Padang, Pariaman Hospital, Aisiyah Pariaman Hospital, and Padang Pariaman Regional Hospital for 2 years. The population in this study consisted of patients with early and late onset preeclampsia who went to the study site during that time and met the inclusion criteria. Sampling with consecutive sampling consisted of 28 people per group.

RESULTS: The results revealed that the number of patients who had urine protein levels with a value of $2+$ at the early onset was 14 and at the late onset was 12, meanwhile for patients with a urine protein content value of $3+$ at the early onset it was 14 and at the late onset was 10 . For the category urine protein with a value of $4+$ amounted to six people only in the late onset group. The results of the normality test showed that the mean value of VEGF levels at early onset and late onset was $3.91 \mathrm{pg} / \mathrm{ml}$ and $4.3 \mathrm{pg} / \mathrm{ml}$, respectively. Thus, the level of VEGF serum had an abnormal distribution and it led to the t-test data could not be tested. So then, the testing was done using a non-parametric test, namely, the Mann-Whitney test. The mean levels of VEGF, respectively, based on the MannWhitney test for early onset preeclampsia and late onset preeclampsia were $29.75 \mathrm{ng} / \mathrm{mL}$ and $30.25 \mathrm{ng} / \mathrm{mL}$. VEGF in early onset preeclampsia is lower than late onset preeclampsia

CONCLUSION: Based on the results obtained, it can be concluded that there was no significant difference in the level of VEGF in early onset preeclampsia and late onset preeclampsia $(p=0.42)$.
\end{abstract}

\section{Introduction}

Preeclampsia is a problem in the field of obstetric health, due to this disease is a high cause of death, namely, 50,000-70,000 female deaths and 500,000 infant deaths each year [1]. The maternal mortality rate (MMR) in Indonesia due to preeclampsia together with infection and bleeding occupies the highest place in ASEAN [2]. Indonesia is one of the developing countries with the high MMR and perinatal mortality with the second rank in the Southeast Asia region and the $3^{\text {rd }}$ rank in ASEAN [3].

Dealing with the onset of occurrence, preeclampsia can be divided into two parts, namely, early onset preeclampsia and late onset preeclampsia [4]. Early onset preeclampsia is preeclampsia that occurs at gestational age $<34$ weeks and late onset preeclampsia is preeclampsia that happens at $>34$ weeks of gestation [5]. Early onset preeclampsia is usually more dangerous than late onset preeclampsia [6]. Early onset preeclampsia is the type that causes the highest maternal and fetal morbidity and mortality rates. In the early onset of preeclampsia, the spiral artery formation is not perfect, resulting in hypoperfusion of the placenta so that the supply of nutrients to the fetus is reduced and eventually fetal growth restriction (FGR) occurs [7]. Whereas, in the late onset of preeclampsia merely experience a slight decrease in the diameter of the spiral arteries and there are no signs of FGR [8].

The clinical appearance of early onset and late onset preeclampsia is similar but there are differences in prognosis, complications, and outcomes of mothers and babies [9], [10]. Early onset 
preeclampsia is usually more dangerous than the late onset preeclampsia [11]. Early onset preeclampsia is the type that causes the highest maternal and fetal morbidity and mortality rates. In the early onset of preeclampsia, the form of spiral artery is not perfect, so then it can lead to the hypoperfusion of the placenta and the supply of nutrients to the fetus is reduced and eventually FGR occurs. Whereas, it is also found that there is merely slight decrease of the diameter of spiral arteries and there are no signs of FGR in the late onset of preeclampsia [12].

Various attempts have been undertaken to reduce maternal mortality, one of which is by conducting the early detection of preeclampsia, among others by examining factors during pregnancy, but these efforts are currently still limited. Several studies have recommended vascular endothelial growth factor (VEGF) testing to detect the possibility of preeclampsia [13].

The examination of urine protein examination is also carried out to pregnant women, this is one type of laboratory examination to discover the function of kidney during pregnancy and identify the presence of both mild and severe preeclampsia which can lead to eclampsia [14]. Proteinuria detection is very essential in the diagnosis and handling the hypertension in pregnancy. Proteinuria is the last symptom to appear in preeclamptic patients. However, eclampsia can occur without proteinuria. Proteinuria in preeclampsia is an indicator of danger to the fetus, low birth weight, and an increased risk of perinatal death [15]. In this study, a study was conducted regarding the description of urine protein levels and analysis of VEGF levels in patients with early onset preeclampsia and late onset preeclampsia.

\section{Methods}

\section{Research population}

The population of study was patients with early onset and late onset preeclampsia who went to RSUP DR. M Djamil Padang, Pariaman Regional Publich Hospital, Aisiyah Pariaman Hospital, and Padang Pariaman Regional Public Hospital during the study period. The study sample was pregnant women with preeclampsia who met the inclusion and exclusion criteria and obtained 28 samples of each for early onset preeclampsia and late onset preeclampsia.

The inclusion criteria in this study were patients that diagnosed with preeclampsia by experts based on clinical appearance, obstetric examinations, and supporting examinations and were willing to be involved in the study. The exclusion criteria in this study were patients with chronic hypertension, patients with gestational hypertension, patients with malignancy, and patients with severe infections.

\section{Sample of blood}

The blood sample taken was venous blood using a syringe aspiration procedure. $4 \mathrm{ml}$ of blood was taken and put into a blood chemistry vacutainer. The vacutainer that already contained of the sample, then, it was given a label name, medical record number, place of birth date, and the name of the patient's birth mother. This sample was put in a vacutainer transport box for later examination in the laboratory.

\section{Statistical analysis}

Statistical analysis of this study used the Statistical Package for the Social Sciences Software (SPSS), version 21.0 (SPSS Inc., Chicago, IL) normality test using the Saphiro-Wilk test. VEGF $p=0.00(p>0.05)$. This data showed that the data that owned were not normally distributed. The results of the data distribution that were not normal and it caused the t-test data testing could not be undertaken, so that data testing was carried out using a non-parametric test, namely, the Mann-Whitney.

\section{Results}

\section{Patient characteristics}

The study sample was pregnant women with preeclampsia who met the inclusion and exclusion criteria and this study obtained 28 samples of each for early onset preeclampsia and late onset preeclampsia. The data of patient characteristics are shown in Table 1.

Table 1: Patient characteristics data

\begin{tabular}{lll}
\hline Parameters & $\begin{array}{l}\text { Early onset Preeclamsia } \\
\mathrm{n}=28(\text { Mean } \pm \mathrm{SD})\end{array}$ & $\begin{array}{l}\text { Late Onset Preeclamsia } \\
\mathrm{n}=28(\text { Mean } \pm \mathrm{SD})\end{array}$ \\
\hline Age $(\mathrm{y})$ & $32.92 \pm 6.06$ & $32.57 \pm 6.61$ \\
Body Weight $(\mathrm{kg})$ & $77.32 \pm 5.26$ & $82.99 \pm 5.40$ \\
Height $(\mathrm{cm})$ & $157.9 \pm 4.09$ & $157.75 \pm 3.08$ \\
Gestational age (week) & $30.85 \pm 1.70$ & $38.53 \pm 1.08$ \\
Systolic Pressure $(\mathrm{mmHg})$ & $160.85 \pm 13.93$ & $166 \pm 10.3$ \\
Diastolic Pressure $(\mathrm{mmHg})$ & $106.85 \pm 5.59$ & $107.64 \pm 6.32$ \\
Urine Protein Level & $2.5 \pm 0.5$ & $2.78 \pm 0.77$ \\
\hline
\end{tabular}

\section{Determination urine protein level}

Examination of urine protein that can be undertaken on pregnant women is one type of laboratory examination to discover the function of kidney during pregnancy and to identify the presence of preeclampsia, both mild and severe, which can lead to eclampsia. The data from the urine protein examination are shown in Figure 1. 


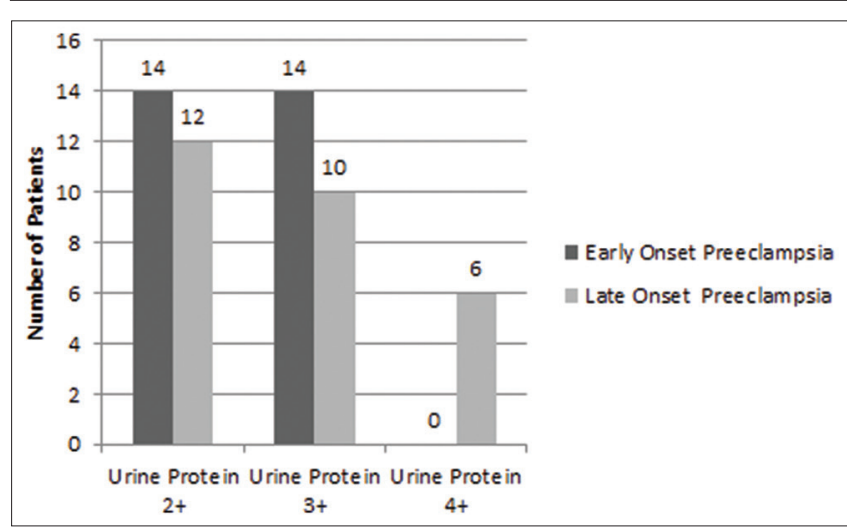

Figure 1: Overview of urine protein levels

\section{The examination result of VEGF serum}

Preeclampsia begins in the first trimester with an asymptomatic phase characterized by insufficiency in the trophoblast invasion process and incomplete remodeling of the spiral arteries. Both of these processes have a role in the increase of oxidative stress and the occurrence of systemic endothelial dysfunction which will lead to preeclamptic symptoms in the final phase of the disease [16]. The role of VEGF as a regulator of angiogenic processes in early pregnancy is quite high and the level of VEGF on the human placenta is inconsistent in the preeclampsia condition. So then, the VEGF has function to detect the possibility of preeclampsia. The result of measuring the serum VEGF levels is shown in Table 2.

Table 2: Data values for serum level of VEGF $(\mathrm{pg} / \mathrm{ml})$

\begin{tabular}{lll}
\hline Patients number & Early onset preeclampsia $(\mathrm{pg} / \mathrm{ml})$ & Late onset preeclampsia $(\mathrm{pg} / \mathrm{ml})$ \\
\hline 1 & 8.47 & 0.204 \\
2 & 4.502 & 1.031 \\
3 & 1.692 & 1.857 \\
4 & 3.51 & 14.422 \\
5 & 0.535 & 5.824 \\
6 & 1.031 & 3.676 \\
7 & 2.188 & 5.66 \\
8 & 3.345 & 4.668 \\
9 & 3.015 & 6.486 \\
10 & 3.676 & 4 \\
11 & 0.039 & 6.652 \\
12 & 1.692 & 5.494 \\
13 & 3.51 & 4.998 \\
14 & 3.841 & 1.031 \\
15 & 2.519 & 0.865 \\
16 & 4.668 & 3.18 \\
17 & 4.833 & 3.51 \\
18 & 6.817 & 4.006 \\
19 & 0.039 & 5.494 \\
20 & 2.023 & 2.188 \\
21 & 6.652 & 1.196 \\
22 & 10.454 & 5.494 \\
23 & 1.527 & 4.502 \\
24 & 8.635 & 3.345 \\
25 & 7.809 & 4.502 \\
26 & 9.131 & 6.817 \\
27 & 0.369 & 6.652 \\
28 & 2.849 & 3.015 \\
Mean \pm SD & $3.9 \pm 2.8$ & $4.3 \pm 2.6$ \\
\hline & &
\end{tabular}

In accordance with the normality test value, serum VEGF levels have an abnormal distribution. The extreme value that appears in sample number 4 is a sample of late onset preeclampsia with a value of $14,422 \mathrm{pq} / \mathrm{ml}$. The results of the data distribution that is not normal, it can cause the t-test data testing cannot be undertaken, so that data testing was undertaken using a non-parametric test, namely, the
Mann-Whitney. The following are the results of the Mann-Whitney test.

\section{Discussion}

Based on the data shown in Figure 1, data obtained that the number of patients who have urine protein levels with a value of $2+$ at the early onset is 14 and at the late onset is 12 , while for patients with a urine protein content value of $3+$ in the early onset is 14 and at the late onset is 10 . For the category of urine protein with a value of $4+$, six people are only in the late onset group. Proteinuria detection is very important in the diagnosis and management of hypertension in pregnancy. Proteinuria is the last symptom to appear in preeclamptic patients. However, preeclampsia can also occur without proteinuria. Proteinuria in preeclampsia is an indicator of danger to the fetus, low-birth weight, and an increased risk of perinatal death.

Table 3 shows that there is no significant difference in VEGF levels in early onset preeclampsia and late onset preeclampsia $(p=0.42)$. The mean levels of VEGF, respectively, based on the MannWhitney test for early onset preeclampsia and late onset preeclampsia were $29.75 \mathrm{ng} / \mathrm{mL}$ and $30.25 \mathrm{ng} /$ $\mathrm{mL}$. VEGF in the early onset of preeclampsia is lower than the late onset of preeclampsia.

Table 3: Mann-Whitney test results of VEGF levels in early onset and late onset preeclampsia

\begin{tabular}{llll}
\hline Groups & Mean Rank & Sum Rank & p-value \\
\hline Early Onset Preeclampsia & 29.75 & 749 & 0.422 \\
Late Onset Preeclampsia & 30.25 & 749 & 0.422 \\
\hline
\end{tabular}

Preeclampsia is closely related to antiangiogenic properties which have a role in the formation of the initial vascularization of the placenta [17]. It is in contrast to VEGF which is classified as a proangiogenic biomarker and is a glycoprotein involved in angiogenesis [18]. VEGF has function to increase proliferation, migration, survival in endothelial cells, and increase capillary permeability [19]. Angiogenesis that promoted by VEGF can occur in both physiological and pathological conditions. Synthesis of VEGF is stimulated when cells are deprived of oxygen, glucose levels, and an inflammatory reaction. VEGF is required for normal growth in vascularization during embryonics, cyclical blood vessel growth in female reproductive organs, and capillary formation during wound repair [20]. The role of VEGF as a regulator of angiogenic processes in early pregnancy is quite high. However, in the human placenta, VEGF levels are not consistent in the condition of preeclampsia [21]. The differences may be related to several factors, including the VEGF isoform that has been examined, it is due to the VEGFA gene that has 25 variants that produce at least 19 protein codes with wide variations 
in bioavailability and biological activity [22]. A study showed based on the expression of mRNA and VEGFA protein its specific variant with 165 amino acids (VEGF165) which is one of the most biologically active isoforms. The results of the study indicated that the mRNA was higher for VEGF165 only for placentas from early onset preeclampsia compared to placentas of normal pregnancy [23].

\section{Conclusion}

The study reported that urine protein levels of $2+$ and $3+$ are greater in early onset than late onset preeclampsia. The concentration of VEGF in the early onset of preeclampsia is lower than the late onset of preeclampsia.

\section{Acknowledgments}

The authors express their profound gratitude and appreciations to the Faculty of Medicine, Andalas University, M Djamil Padang Hospital, Pariaman Hospital, Aisiyah Pariaman Hospital, and Padang Pariaman Hospital for supporting this research.

\section{References}

1. Li XL, Chen TT, Dong X, Gou WL, Lau S, Stone P, et al. Early onset preeclampsia in subsequent pregnancies correlates with early onset preeclampsia in first pregnancy. Eur $\mathrm{J}$ Obstet Gynecol Reprod Biol. 2014;177:94-9. https://doi.org/10.1016/j. ejogrb.2014.03.043

PMid:24784713

2. National Research Council. Reducing Maternal and Neonatal Mortality in Indonesia: Saving Lives, Saving the Future. Washington, DC: National Academies Press; 2013. https://doi. org/10.17226/18437

3. Raghupathy R. Cytokines as key players in the pathophysiology of preeclampsia. Med Princ Pract. 2013;22 Suppl 1:8-19. https:// doi.org/10.1159/000354200

\section{PMid:23949305}

4. Wojtowicz A, Zembala-Szczerba M, Babczyk D, KołodziejczykPietruszka M, Lewaczyńska O, Huras H. Early-and lateonset preeclampsia: A comprehensive cohort study of laboratory and clinical findings according to the new ISHHP criteria. Int J Hypertens. 2019;2019:4108271. https://doi. org/10.1155/2019/4108271

PMid:31637053

5. Lisonkova S, Joseph KS. Incidence of preeclampsia: Risk factors and outcomes associated with early-versus late-onset disease. Am J Obstet Gynecol 2013;209(6):544.e1-12. https:// doi.org/10.1016/j.ajog.2013.08.019

PMid:23973398

6. Lisonkova S, Sabr Y, Mayer C, Young C, Skoll A, Joseph KS Maternal morbidity associated with early-onset and lateonset preeclampsia. Obstet Gynecol. 2014;124(4):771-81. https://doi.org/10.1097/aog.0000000000000472 PMid:25198279

7. Saadat M, Nejad SM, Habibi G, Sheikhvatan M. Maternal and neonatal outcomes in women with preeclampsia. Taiwan J Obstet Gynecol. 2007;46(3):255-9. https://doi.org/10.1016/ s1028-4559(08)60029-7

PMid: 17962105

8. Espinoza J, Romero R, Kim YM, Kusanovic JP, Hassan S, Erez O, et al. Normal and abnormal transformation of the spiral arteries during pregnancy. J Perinat Med. 2006;34(6):447-58. https://doi.org/10.1515/jpm.2006.089

PMid:17140293

9. Huppertz B. Placental origins of preeclampsia: Challenging the current hypothesis. Hypertension. 2008;51(4):970-5. https://doi. org/10.1161/hypertensionaha.107.107607

PMid:18259009

10. Stubert J, Ullmann S, Dieterich M, Diedrich D, Reimer T. Clinical differences between early-and late-onset severe preeclampsia and analysis of predictors for perinatal outcome. J Perinat Med. 2014;42(5):617-27. https://doi.org/10.1515/jpm-2013-0285 PMid:24778345

11. Herzog EM, Eggink AJ, Reijnierse A, Kerkhof MA, de Krijger RR, Roks AJ, et al. Impact of early-and late-onset preeclampsia on features of placental and newborn vascular health. Placenta. 2017;49:72-9. https://doi.org/10.1016/j.placenta.2016.11.014 PMid:28012458

12. Foo FL, Mahendru AA, Masini G, Fraser A, Cacciatore $S$, Maclntyre DA, et al. Association between prepregnancy cardiovascular function and subsequent preeclampsia or fetal growth restriction. Hypertension. 2018;72(2):442-50. https://doi. org/10.1161/hypertensionaha.118.11092

PMid:29967040

13. Parra $M$, Rodrigo R, Barja $P$, Bosco $C$, Fernández V, Muñoz $H$, et al. Screening test for preeclampsia through assessment of uteroplacental blood flow and biochemical markers of oxidative stress and endothelial dysfunction. Am J Obstet Gynecol. 2005;193(4):1486-91. https://doi.org/10.1016/j. ajog.2005.02.109

PMid: 16202744

14. Al RA, Baykal C, Karacay O, Geyik PO, Altun S, Dolen I. Random urine protein-creatinine ratio to predict proteinuria in new-onset mild hypertension in late pregnancy. Obstet Gynecol. 2004;104(2):367-71. https://doi.org/10.1097/01. aog.0000134788.01016.2a

PMid:15292013

15. Berks D, Steegers EA, Molas M, Visser W. Resolution of hypertension and proteinuria after preeclampsia. Obstet Gynecol. 2009;114(6):1307-14. https://doi.org/10.1097/ aog. $0 \mathrm{~b} 013 \mathrm{e} 3181 \mathrm{c} 14 \mathrm{e} 3 \mathrm{e}$ PMid: 19935034

16. George EM, Granger JP. Recent insights into the pathophysiology of preeclampsia. Expert Rev Obstet Gynecol. 2010;5(5):557-66. PMid:21170149

17. Kaufmann P, Mayhew TM, Charnock-Jones DS. Aspects of human fetoplacental vasculogenesis and angiogenesis. II. Changes during normal pregnancy. Placenta. 2004;25(2-3):11426. https://doi.org/10.1016/j.placenta.2003.10.009 PMid: 14972444

18. Mashreghi M, Azarpara H, Bazaz MR, Jafari A, Masoudifar A, 
Mirzaei $\mathrm{H}$, et al. Angiogenesis biomarkers and their targeting ligands as potential targets for tumor angiogenesis. J Cell Physiol. 2018;233(4):2949-65. https://doi.org/10.1002/ jcp.26049

PMid:28608549

19. Byrne AM, Bouchier-Hayes DJ, Harmey JH. Angiogenic and cell survival functions of vascular endothelial growth factor (VEGF). J Cell Mol Med. 2005;9(4):777-94. https://doi. org/10.1111/j.1582-4934.2005.tb00379.x

PMid:16364190

20. Harry LE, Paleolog EM. From the cradle to the clinic: VEGF in developmental, physiological, and pathological angiogenesis. Birth Defects Res C Embryo Today. 2003;69(4):363-74. https:// doi.org/10.1002/bdrc.10024

PMid:14745976

21. Demir R, Kayisli UA, Seval Y, Celik-Ozenci C, Korgun ET, Demir-Weusten AY, et al. Sequential expression of VEGF and its receptors in human placental villi during very early pregnancy: Differences between placental vasculogenesis and angiogenesis. Placenta. 2004;25(6):560-72. https://doi. org/10.1016/j.placenta.2003.11.011

PMid:15135240

22. Ackerman C, Locke AE, Feingold E, Reshey B, Espana K, Thusberg J, et al. An excess of deleterious variants in VEGF-a pathway genes in down-syndrome-associated atrioventricular septal defects. Am J Hum Genet. 2012;91(4):646-59. https:// doi.org/10.1016/j.ajhg.2012.08.017

PMid:23040494

23. Escudero C, Celis C, Saez T, San Martin S, Valenzuela FJ, Aguayo C, et al. Increased placental angiogenesis in late and early onset pre-eclampsia is associated with differential activation of vascular endothelial growth factor receptor 2. Placenta. 2014;35(3):207-15. https://doi. org/10.1016/j.placenta.2014.01.007

PMid:24508097 